\title{
A Novel Strategy for Drug Discovery and Development by Analyzing the Behavior of ES Cells Cultured on TOSHI (Tissue/Organ Sections for Histopathology)-Substrata
}

\author{
Toshiaki Takezawa \\ National Institute of Agrobiological Sciences, \\ Japan
}

\section{Introduction}

To create new in vitro culture models for extrapolating the cell response in vivo, Takezawa et al. have attempted to devise culture substrata of anchorage-dependent cells (Takezawa et al., 1990; Takezawa et al., 1992; Takezawa \& Yoshizato, 1997; Takezawa et al., 2000; Takezawa et al., 2002; Takezawa, 2003; Takezawa et al., 2004; Takezawa et al., 2007a; Takezawa et al., 2007b; Takezawa et al., 2008a; Takezawa et al., 2008b; Takezawa et al., 2010). One model is a culture system utilizing substrata made of tissue/organ sections for histopathology (TOSHI), which was found to conserve both tissue components and microarchitecture in an in vivo environment (Takezawa et al., 2002; Takezawa, 2003).

Meanwhile, it is reported that mouse embryonic stem (ES) cells injected into the tail veins of carbon tetrachloride $\left(\mathrm{CCl}_{4}\right)$ liver-injured mouse were differentiated into hepatocyte-like cells in the host liver (Yamamoto et al., 2003). Therefore, we investigated whether the ES cells could also be differentiated into hepatocyte-like cells when they were cultured on the TOSHI-substrata prepared from livers in various stages after $\mathrm{CCl}_{4}$ administration into mice. Consequently, it was found that the substrata derived from regenerating livers enhanced cell attachment, supported growth as clusters, and induced differentiation into cells expressing albumin, although the substrata from injured livers did not. In particular, the cells cultured on the most proliferative regenerating liver-derived substratum reconstructed the hepatic cord-like structures with bile canaliculus-like aspects in which some binucleated cells were involved, secreted albumin, and expressed cytochrome P450IA1 activity within a few days (Takeuchi et al., 2008; Takezawa et al., 2008; Takezawa et al., 2008b).

These data suggest two advantages based on the behavior of ES cells in a culture system utilizing TOSHI-substrata; one is that TOSHI-substratum derived from regenerating livers with high proliferative potential efficiently induced the differentiation of ES cells toward hepatic lineage and another is that ES cells functioned as a sensor recognizing liver toxicity in TOSHI-substratum derived from injured livers after $\mathrm{CCl}_{4}$ administration into mice. Therefore, it is considered that the former would be available for the novel approach of drug discovery to find bioactive factors and the latter provide a new alternative method of animal experiments in toxicology to support drug development. 
In this chapter, I propose a novel strategy for drug discovery and development by analyzing the behavior of ES cells cultured on TOSHI-substrata. Section 2 describes the basics and advantages of a cell culture system utilizing TOSHI-substrata. Section 3 presents behavior of mouse ES cells cultured on TOSHI-substrata derived from livers in various stages after $\mathrm{CCl}_{4}$ administration into mice. Section 4 proposes a novel concept for drug discovery and development utilizing the behavior of ES cells cultured on TOSHI-substrata. Section 5 presents a discussion and summarizes the paper.

\section{The basics and advantages of a cell culture system utilizing TOSHI- substrata}

In this section I describe the basic outline of a cell culture system utilizing TOSHI-substrata and the advantages of investigating cell behavior on TOSHI-substrata. A novel idea for diagnosing characteristics of undefined cells and tissues will be introduced as applied concepts for "cellomics" and "histomics", respectively.

\subsection{The basic outline of a cell culture system utilizing TOSHI-substrata}

A lot of cell culture substrata that control multicellular behaviors have been developed from natural or synthetic or their hybrid materials and are currently utilized for reconstructing organoids as cellular scaffold(s) in tissue/organ engineering (Takezawa et al., 2000). However, no one has succeeded in producing a culture substratum reflecting the complex architecture of various cellular microenvironments in tissues in vivo. On the other hand, thin tissue/organ sections commonly prepared on a glass slide for histopathology retain many in vivo biochemical attributes related not only to structure but also function. We hypothesized that such tissue/organ sections might serve as novel cell culture substrata that would reflect conditions in vivo.

In the beginning study, such novel culture substrata made of tissue/organ sections for histopathology (TOSHI-substrata) were prepared from a frozen bovine placenta embedded in an OCT compound, and subsequently four different types of cells were cultured on the substrata. As the results, the labyrinth region of the substratum induced unique cell behaviors to form multicellular spheroids of BeWo cells (human choriocarcinoma cell line), a capillary network-like structure of CPAE cells (bovine pulmonary artery endothelial cell line), and a neuronal network-like structure of PC-12 cells (rat pheochromocytoma cell line). The substratum provided a microenvironment that maintained the viability of PC-12 cells under serum-free conditions. Also, we succeeded in preparing a multicellular mass of NHDFs (normal human dermal fibroblasts) with acellularized section-derived components (Takezawa et al., 2002).

The typical experimental procedure for a cell culture system utilizing TOSHI-substrata was shown in Figure 1.

\subsection{The advantages of investigating cell behavior on TOSHI-substrata}

TOSHI-substrata can be prepared various tissues and every cell line can be cultured on the TOSHI-substrata, and consequently we can analyze the behavior of each cell line induced by each TOSHI-substratum. Therefore, we consider that it will be available to construct the database cumulated diverse interactions between culture cells and tissues/organs of the substrata. As the first step, we recently prepared TOSHI-substrata from normal rat mature organs (cerebrum, thymus, heart, liver, kidney and testis) in a frozen state and cultured two 
(1) Preparation of a frozen, paraffin-embedded, or resin-embedded tissue/organ

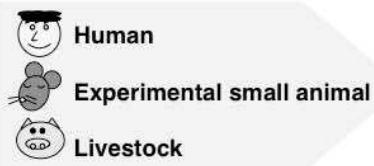

Livestock

\section{Excising a whole or partial tissue/organ}

Normal

Abnormal

(derived from a focus of disease, e.g. cancer) 1

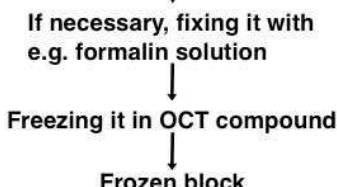

Fixing it with e.g. formalin solution and embedding it in paraffin or resin

$\left\{\begin{array}{l}\text { Paraffin block } \\ \text { Resin block }\end{array}\right.$

(2) Preparation of TOSHI (tissue/organ sections for histopathology)-substrata

\section{Cutting a block} using a microtome

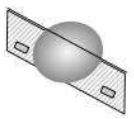

Thickness of sections

ca. $5 \mu \mathrm{m}$ for frozen block

ca. $4 \mu \mathrm{m}$ for paraffin block $\left\{\begin{array}{l}\text { ca. } 2 \mu \mathrm{m} \text { for resin block } \\ \text { ca. } 2 \mu \mathrm{m} \text { foratin }\end{array}\right.$
Spreading sections on a glass slide, then removing OCT compound and paraffin from frozen and paraffin sections, respectively

(3) If necessary, modification of the TOSHI-substrata by chemical, biological and/or physical treatment

Chemical treatment : surfactants for decellularlzation, organic solvents for removing fats, etc.

$\{$ Biological treatment : antibodies for blocking antigens, enzymes for inducing metabolites, etc.

Physical treatment : ultraviolet radiation or heating for denaturing proteins

(4) Optimization of the TOSHI-substrata for cell culture in a tray

Transferring TOSHI-substrata

to a tray for cell culture

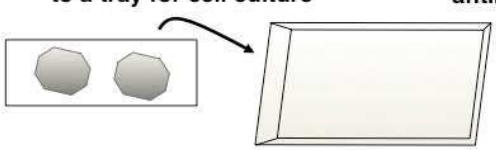

(5) Cell culture on the TOSHI-substrata

Seeding and culturing cells on the TOSHI-substrata
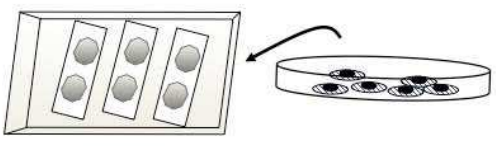

Removing or reducing serum in the culture medium to sufficiently induce the TOSHI-substrata-derived effects on cell behavior

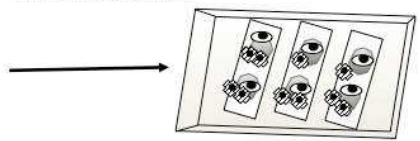

(6) Time-course analysis of the cell behavior in culture

Fig. 1. Schematic procedure for preparing TOSHI (tissue/organ sections for histopathology) -substrata and culturing cells on it. Reproduced and partially-modified with permission of the publisher (Takezawa et al., 2008a). 
different cell lines (RIN5F cells of rat insulinoma and HepG2 cells of human hepatoma) to compare their behaviors on the substrata. As the results, RIN5F cells showed high attachability onto the TOSHI-substrata derived from heart and kidney, standard growth on the substrata from heart, kidney, and liver, and high level of insulin secretion on the substratum from thymus. Whereas HepG2 cells showed low attachability onto the TOSHIsubstrata derived from liver, and kidney and not only standard growth but also standard level of albumin secretion on the substrata from cerebrum, thymus, heart, liver, kidney and testis. Also, the time-course profiles for cell growth and secretion level of insulin or albumin on each TOSHI-substratum were successfully converted into a three-dimensional graph chart, i.e. a mathematical model. In conclusion, it was demonstrated that the mathematical profile describing cell behavior was specific for the combination of a cell line and a tissue/organ of the substrata (Yanagihara et al., 2007). These findings suggest that we can provide novel research concept for cellomics and histomics (Fig. 2). Here, cellomics and histomics facilitate comprehensive analyses for various cell lines using one tissue/organderived TOSHI-substratum and for various tissue/organ-derived TOSHI-substrata using one cell line, respectively. In future, the database construction for cellomics and histomics would lead a new system for diagnosing characteristic-unknown cell line or a characteristicunknown TOSHI-substratum by feedback of the cell behavior profile obtained from the combinations of "a characteristic-unknown cell line and characteristic-known TOSHIsubstrata" or "characteristic-known cell lines and a characteristic-unknown TOSHIsubstratum" to the database.

Further, applied researches such as induction of cell differentiation, serum-free culture, exploration and/or production of bioactive molecules, estimation of gene function, and reconstruction of tissues will be achieved by designing an appropriate combination of a cell line and a TOSHI-substratum.

\section{Behavior of mouse ES cells cultured on TOSHI-substrata derived from livers in various stages after $\mathbf{C C l}_{4}$ administration into mice}

In this section I mainly describe our previous study to differentiate mouse ES cells towards hepatic lineage utilizing TOSHI-substrata derived from regenerating livers after $\mathrm{CCl}_{4}$ administration into mice (Takeuchi et al., 2008), then briefly introduce a new strategy for predicting the toxicity of chemicals.

\subsection{Background for the study to differentiate mouse ES cells towards hepatic lineage}

Embryonic stem (ES) cells differentiate into tissues of all the three germ layers, and the effort is to restrict or direct their development to specific cell type or lineage. A number of studies have attempted to produce hepatocytes from ES cells and have successfully induced hepatic development in vitro (Ishi et al., 2005; Lavon \& Benvenisty, 2005; Novik et al., 2006; Teratani et al., 2005; Zhou et al., 2007). However, all these studies have used culture systems supplemented by a temporal series of growth factors similar to those known to control embryonic liver development and therefore limited success, e.g. low efficacy of hepatic differentiation or it takes long period. Meanwhile, mouse ES cells injected into the tail vein of carbon tetrachloride $\left(\mathrm{CCl}_{4}\right)$ liver-injured mouse were differentiated into hepatocyte-like cells in the host liver (Yamamoto et al., 2003). Here, we aimed to investigate whether the ES cells could also be differentiated into hepatocyte-like cells when they were cultured on the TOSHI-substrata prepared from livers in various stages after $\mathrm{CCl}_{4}$-administration into mice. 


\section{Cellomics profile}

\section{Various cell lines}

Cell type-A Cell type-B Cell type-C...

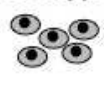

$$
00
$$

A tissue-derived TOSHI-substratum
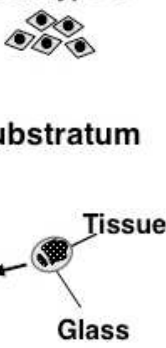

24 well-plate
Histomics profile

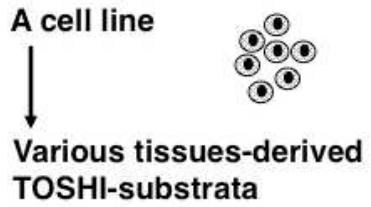

Tissue type-A Tissue type-B Tissue type-C...
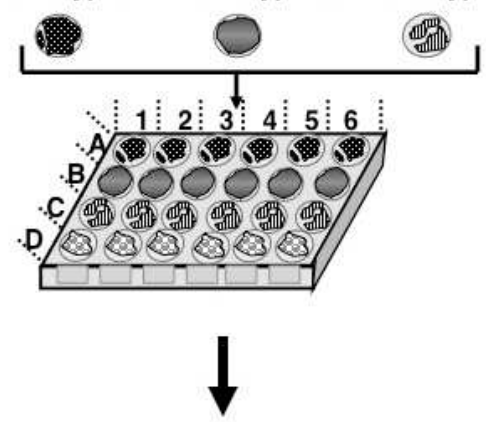

\begin{tabular}{|c|c|l|l|}
\hline & Tissue-A & Tissue-B & Tissue-C $\cdots$ \\
\hline \multirow{2}{*}{ Day 1 } & $\mathrm{a}:+$ & $\mathrm{a}:+$ & $\mathrm{a}:+$ \\
& $\mathrm{g}:-$ & $\mathrm{g}:+$ & $\mathrm{g}:-$ \\
& $\mathrm{d}:-$ & $\mathrm{d}:-$ & $\mathrm{d}:-$ \\
\hline \multirow{2}{*}{ Day 2 } & $\mathrm{a}:+$ & $\mathrm{a}:+$ & $\mathrm{a}:+$ \\
$\mathrm{g}:+$ & $\mathrm{g}:-$ & $\mathrm{g}:++$ \\
$\vdots$ & $\mathrm{d}:-$ & $\mathrm{d}:-$ & $\mathrm{d}:+$ \\
\hline
\end{tabular}

a (attachability), g (growth), d (differentiation) - (none), + (good), ++ (excellent).

\section{- (none),+ (good),++ (excellent).}

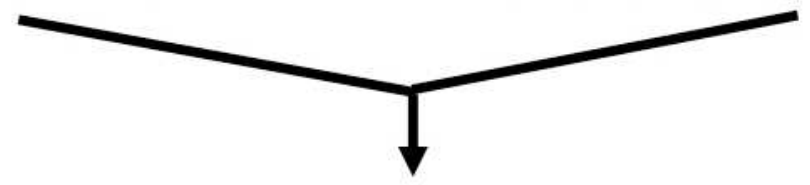

Mathematical models of each profile
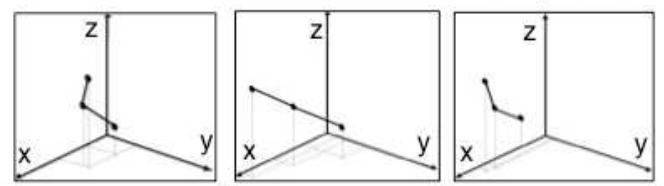

$\mathbf{x}:$ Growth

... $\mathrm{y}:$ Differentiated function

Cell-A / Tissue-A Cell-B / Tissue-A Cell-B / Tissue-B

$z:$ Time in culture

\section{Cellomics}

Histomics

Fig. 2. Novel research concept for cellomics and histomics. Reproduced and partiallymodified with permission of the publisher (Takezawa et al., 2008a). 
3.2 Preparation of TOSHI-substrata reflecting liver failure and regeneration after $\mathrm{CCl}_{4}-$ administration into mice

Male mice (129SV) were purchased from CLEA. Light liver injury was caused by intraperitoneally injecting $100 \mu \mathrm{l}$ of olive oil containing $10 \mu \mathrm{l}$ of $\mathrm{CCl}_{4}$ into 8 week-old mice weighing between 18 and $23 \mathrm{~g}$ to induce liver regeneration. As a control, $100 \mu \mathrm{l}$ of olive oil alone was intraperitoneally injected into other mice. The blood sera and livers of the mice at 12, 24 and $48 \mathrm{~h}, 4,7$ and 15 days after $\mathrm{CCl}_{4}$-administration and at $24 \mathrm{~h}$ after olive oiladministration were subjected to the measurement of aspartate aminotransferase (AST) leakage level and the preparation of TOSHI-substrata, respectively. Livers were excised immediately after sacrificing the mice, embedded in an OCT compound and rapidly frozen with liquid nitrogen. The frozen livers were cut into sections with a thickness of $5 \mu \mathrm{m}$. The liver-derived sections were spread onto a glass slide and air-dried to yield TOSHI-substrata. All animal experiments were performed in accordance with the guidelines of the Experimental Animal Committee at the National Institute of Agrobiological Sciences.

$\mathrm{CCl}_{4}$-treated mice
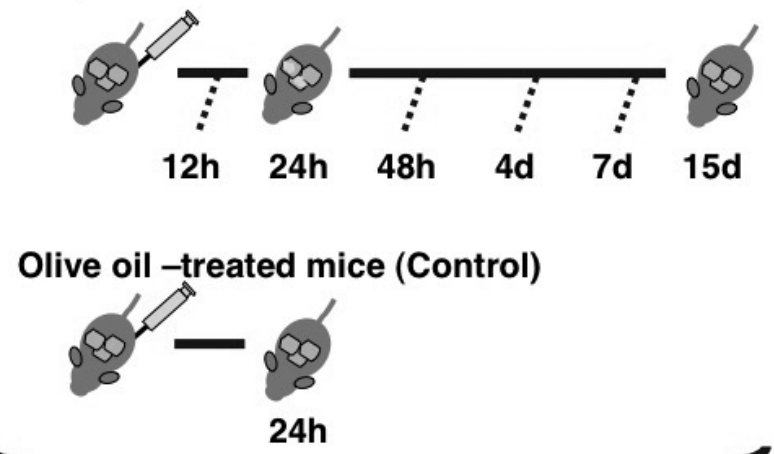

Analyses of liver failure and regeneration

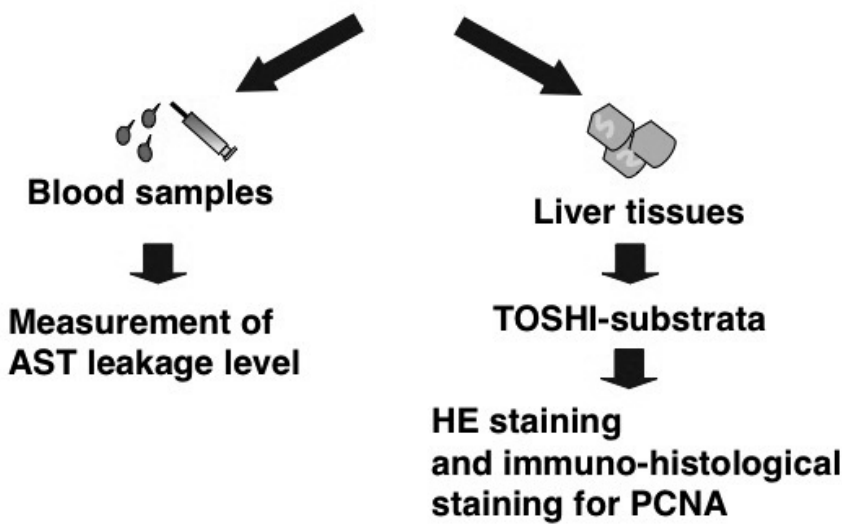

Fig. 3. Analytical protocol of liver failure and regeneration after $\mathrm{CCl}_{4}$-administration into mice. 
To investigate the time-course changes of liver failure and regeneration, the AST leakage level in blood sera was measured by utilizing an assay kit for AST (Wako). Also, TOSHIsubstrata without culturing cells were subjected to standard hematoxylin and eosin (HE) staining and immuno-histological staining for proliferating cell nuclear antigen (PCNA), and observed by a light microscope. Subsequently, the PCNA-positive cell number in a unit area of $1.31 \mathrm{~mm}^{2}$ on each substratum was counted from three independent microphotographs (Fig. 3).

As a result, the serum AST level of liver-injured mice increased more than three times from 12 to $48 \mathrm{~h}$ after $\mathrm{CCl}_{4}$-administration, then gradually decreased and finally recovered on day 15 (Table 1). Meanwhile, immuno-histological observations of liver-derived TOSHIsubstrata revealed that the PCNA-positive cell number increased in mice from $24 \mathrm{~h}$ to 7 days after $\mathrm{CCl}_{4}$-administration and that the peak representing about 27 -fold of the control mice was seen in mice on day 4 (Table 1). Also, this progression process of liver failure and regeneration was clearly confirmed by observation of the TOSHI-substrata stained with HE (Takeuchi et al., 2008).

\subsection{Culture of mouse ES cells on TOSHI-substrata reflecting liver failure and regeneration after $\mathrm{CCl}_{4}$-administration into mice}

Mouse ES cells, J1 cell clones of 129SV male origin, and pALB-EGFP/ES cells [a stable mouse ES J1 cell line carrying a plasmid vector of pALB-EGFP which drives expression of albumin promoter-induced green fluorescent protein (GFP)] were sub-cultured on feeder fibroblasts according to the previous method (Teratani et al., 2005; Yamamoto et al., 2003). TOSHIsubstrata reflecting liver failure and regeneration after $\mathrm{CCl}_{4}$-administration, a control TOSHIsubstratum prepared from a liver of the mice at $24 \mathrm{~h}$ after olive oil-administration, and a TOSHI-free glass slide substratum were subjected to the optimization for cell culture. Each substratum was inserted into a well of 4-well culture plates (Greiner), and immersed twice in phosphate buffered saline (PBS) containing 200 units $/ \mathrm{ml}$ penicillin and $200 \mathrm{\mu g} / \mathrm{ml}$ streptomycin for $10 \mathrm{~min}$ and once in the culture medium for $5 \mathrm{~min}$ before use.

To investigate cell attachability, growth, morphology and differentiation into the cells expressing albumin, the suspension of pALB-EGFP/ES cells prepared in a culture medium [Dulbecco's Modified Eagle Medium with $4.5 \mathrm{~g} / 1$ glucose (DMEM) containing 20\% heatinactivated fetal bovine serum (FBS), 1,000 units/ml leukemia inhibitory factor (LIF) (ESGRO; Chemicon), $100 \mu \mathrm{M}$ 2-mercaptoethanol (2-ME), $0.1 \mathrm{mM}$ non-essential amino acids, $30 \mu \mathrm{M}$ Adenosine, $30 \mu \mathrm{M}$ Guanosine, $30 \mu \mathrm{M}$ Cytidine, $30 \mu \mathrm{M}$ Uridine, $10 \mu \mathrm{M}$ Thymidine, 100 units $/ \mathrm{ml}$ penicillin, $100 \mu \mathrm{g} / \mathrm{ml}$ streptomycin and $250 \mathrm{ng} / \mathrm{ml}$ Amphotericin B] was seeded on each substratum at an initial cell density of $1.0 \times 10^{5}$ cells $/ \mathrm{cm}^{2}$ (Fig. 4). The cells were cultured at $37 \circ \mathrm{C}$ in a humidified atmosphere of $5 \% \mathrm{CO}_{2}$ in air and the culture media were once changed to basal media of a DMEM alone at $2 \mathrm{~h}$ in culture. The morphology and GFP expression of pALB-EGFP/ES cells cultured on each substratum were observed over time by a phasecontrast microscope and a fluorescent one under the same visual field, respectively. For analyzing the attachability, growth and differentiation of pALB-EGFP/ES cells, the area of the regions occupied by cells in a unit area of $1.18 \mathrm{~mm}^{2}$ on each substratum at $2,8,16,24$ and $48 \mathrm{~h}$ in culture and that of their GFP-positive parts at $24 \mathrm{~h}$ were measured by applying NIH image software to computer images converted from three independent microphotographs, and consequently the ratio of the area occupied by cells and the appearance ratio of GFP-positive cells among the cells on each substratum were calculated, respectively. Similarly, each area of 
ten cell colonies on the $\mathrm{CCl}_{4}-4 \mathrm{~d}$ substratum and the appearance ratio of GFP-positive cells in each colony were calculated at $2,8,16,24,48,96$ and $168 \mathrm{~h}$ in culture.

As a result, the initial cell attachment onto the control TOSHI-substratum prepared from livers at $24 \mathrm{~h}$ after olive oil-administration into mice (cont.-substratum) was 1.7-hold higher than that onto the glass slide-substratum (glass-substratum). As compared to the cont.substratum, the TOSHI-substratum prepared from livers at $12 \mathrm{~h}$ after $\mathrm{CCl}_{4}$-administration into mice $\left(\mathrm{CCl}_{4}-12 \mathrm{~h}\right.$ substratum) suppressed the attachment of ES cells whereas the $\mathrm{CCl}_{4}-4 \mathrm{~d}$ and $\mathrm{CCl}_{4}-7 \mathrm{~d}$ substrata promoted it (Table 1). The population of pALB-EGFP/ES cells cultured in the basal media gradually decreased on any substratum except for the $\mathrm{CCl}_{4}-4 \mathrm{~d}$ substratum as the culture period increased. Most colonies on the $\mathrm{CCl}_{4}-4 \mathrm{~d}$ substratum expanded their size until 16 or $24 \mathrm{~h}$ in culture, and subsequently reduced the size due to spontaneous detachment of the colony cells from the substratum. About $10 \%$ of the colonies on the $\mathrm{CCl}_{4}-4 \mathrm{~d}$ substratum enlarged its size more than 4 -fold at $24 \mathrm{~h}$, suggesting the colony cells divided about 2 times within $24 \mathrm{~h}$. Furthermore, GFP-positive cells indicating the albumin expression appeared in some colonies formed on the $\mathrm{CCl}_{4}-4 \mathrm{~d}$ substratum at $16 \mathrm{~h}$ in culture and were still observed at $168 \mathrm{~h}$. To the contrary, pALB-EGFP/ES cells cultured on the glass-, cont.-, $\mathrm{CCl}_{4}-12 \mathrm{~h}, \mathrm{CCl}_{4}-24 \mathrm{~h}$ substrata did not express GFP. The extent of GFP positive cells on the $\mathrm{CCl}_{4}-48 \mathrm{~h}, \mathrm{CCl}_{4}-4 \mathrm{~d}, \mathrm{CCl}_{4}-7 \mathrm{~d}, \mathrm{CCl}_{4}-15 \mathrm{~d}$ substrata was about $46,70,24$, $26 \%$ of the cells at $24 \mathrm{~h}$ in culture, respectively (Table 2). Morphological observation revealed

\begin{tabular}{lcccccc}
\hline Time after $\mathrm{CCl}_{4}$-administration & $12 \mathrm{~h}$ & $24 \mathrm{~h}$ & $48 \mathrm{~h}$ & $4 \mathrm{~d}$ & $7 \mathrm{~d}$ & $15 \mathrm{~d}$ \\
\hline AST leakage level & 3.12 & 3.38 & 3.12 & 2.37 & 1.37 & 1.07 \\
\hline PCNA-positive cells & 0.66 & 3.31 & 2.66 & 26.6 & 6.06 & 0.38 \\
\hline Cell attachability & 0.69 & 0.89 & 1.07 & 1.20 & 1.20 & 0.94 \\
\hline
\end{tabular}

Table 1. Ratio changes of AST leakage level in sera, PCNA-positive cells and cell attachability in TOSHI-substrata at $12 \mathrm{~h}, 24 \mathrm{~h}, 48 \mathrm{~h}, 4 \mathrm{~d}, 7 \mathrm{~d}$ and $15 \mathrm{~d}$ after $\mathrm{CCl}_{4}$-administration in comparison to the control serum and TOSHI-substratum at $24 \mathrm{~h}$ after olive oiladministration. The initial cell attachability onto each substratum were examined after culturing the cells in a culture medium mainly supplemented with fetal bovine serum, leukemia inhibitory factor, and 2-mercaptoethanol for $2 \mathrm{~h}$.

\begin{tabular}{ccccccccc}
\hline $\begin{array}{l}\text { Toshi-free } \\
\text { substratum }\end{array}$ & & \multicolumn{7}{c}{ Toshi-substrata } \\
\cline { 1 - 5 } \cline { 5 - 8 } Glass & & Control & $\mathrm{CCl}_{4}-12 \mathrm{~h}$ & $\mathrm{CCl}_{4}-24 \mathrm{~h}$ & $\mathrm{CCl}_{4}-48 \mathrm{~h}$ & $\mathrm{CCl}_{4}-4 \mathrm{~d}$ & $\mathrm{CCl}_{4}-7 \mathrm{~d}$ & $\mathrm{CCl}_{4}-15 \mathrm{~d}$ \\
\hline $0 \%$ & $0 \%$ & $0 \%$ & $0 \%$ & $45.9 \%$ & $69.8 \%$ & $23.8 \%$ & $25.8 \%$ \\
\hline
\end{tabular}

Table 2. The ratio of GFP positive cells in the cells cultured on the indicated substrata for $24 \mathrm{~h}$. 


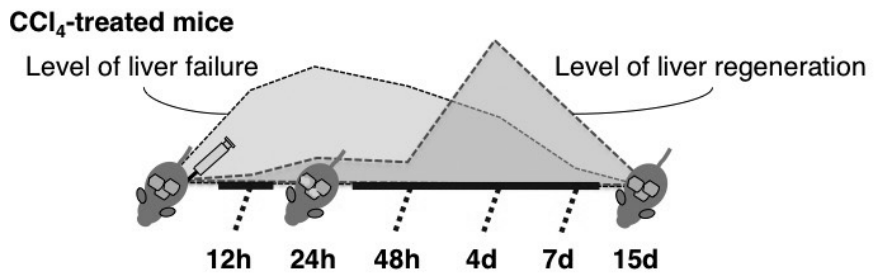

Olive oil -treated mice (Control)
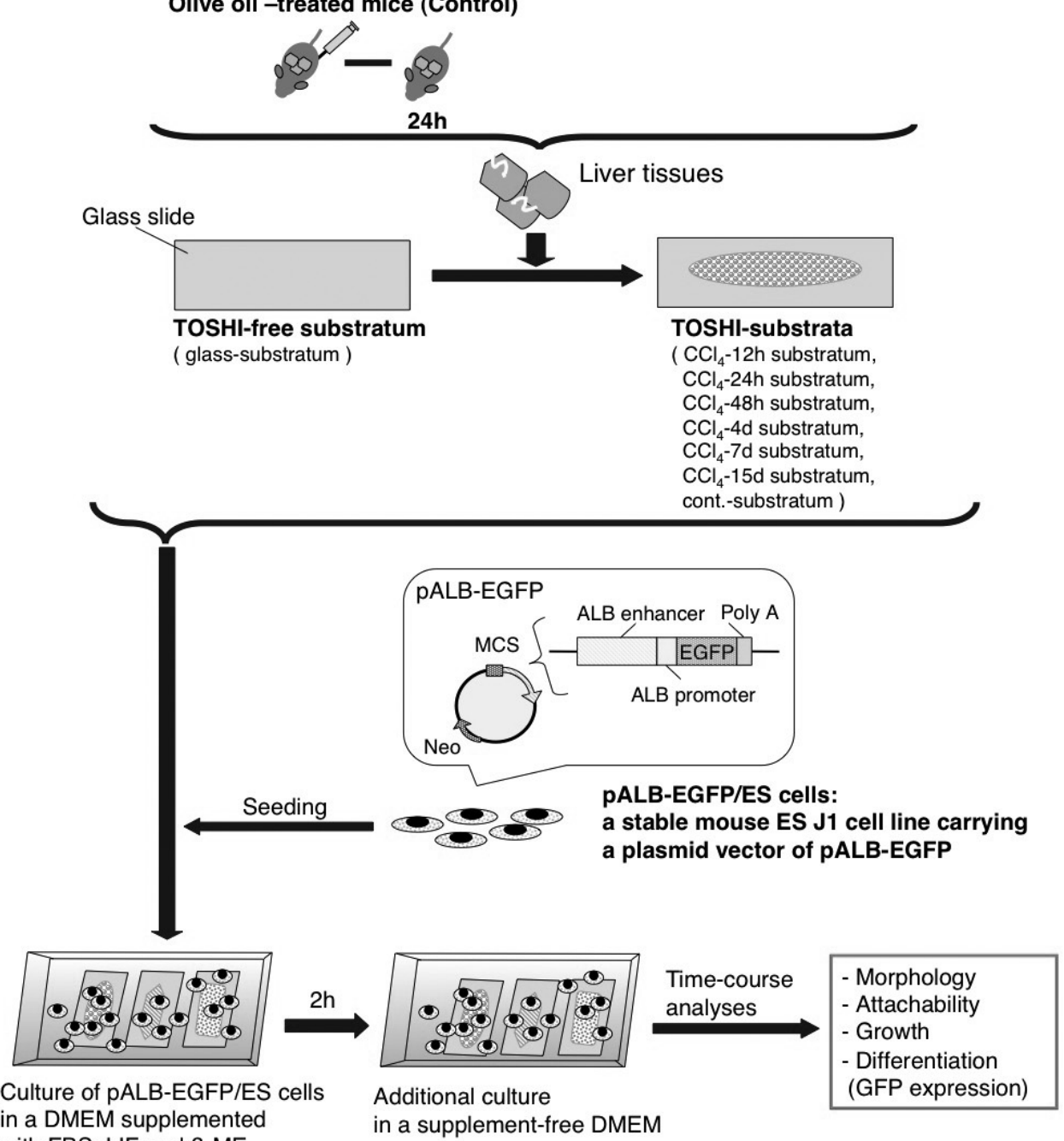
with FBS, LIF and $\beta$-ME

Fig. 4. Experimental protocol of investigating the behavior of pALB-EGFP/ES cells cultured on TOSHI-substrata reflecting liver failure and regeneration after $\mathrm{CCl}_{4}$-administration. 
that pALB-EGFP/ES cells cultured for $24 \mathrm{~h}$ on the glass-, cont.-, $\mathrm{CCl}_{4}-12 \mathrm{~h}, \mathrm{CCl}_{4}-24 \mathrm{~h}$ substrata were remarkably reduced in number due to spontaneous detachment from each substratum, and that the retained cells relatively small and round in shape were individually scattered on each substratum and entirely negative for GFP expression. In contrast, those on the $\mathrm{CCl}_{4}-48 \mathrm{~h}, \mathrm{CCl}_{4}-4 \mathrm{~d}, \mathrm{CCl}_{4}-7 \mathrm{~d}, \mathrm{CCl}_{4}-15 \mathrm{~d}$ substrata mostly participated in forming clusters in which the cells tended to express GFP and relatively large colonies were observed on the sinusoidal capillary region of the $\mathrm{CCl}_{4}-4 \mathrm{~d}$ and $\mathrm{CCl}_{4}-7 \mathrm{~d}$ substrata. In particular, the colonies on the $\mathrm{CCl}_{4}-4 \mathrm{~d}$ substratum showed reconstruction of hepatic cordlike structures with bile canaliculus-like aspects (Harada et al., 2003) between the cells in polygonal shape and most of the colony cells expressed GFP.

Further, to investigate any changes in hepatic morphology and function ES cells were seeded and cultured on the $\mathrm{CCl}_{4}-4 \mathrm{~d}$ substratum (Fig. 5). The culture medium mainly containing FBS, LIF and 2-ME was changed to a basal medium without the supplements at 2 $h$ to estimate the effect of the substratum on cell growth and differentiation after inducing cell adherence under the presence of serum. ES cells cultured on the $\mathrm{CCl}_{4}-4 \mathrm{~d}$ substratum for $24 \mathrm{~h}$ were stained with HE and observed by a light microscope. The albumin secretion level into a culture medium was measured by utilizing an assay kit for mouse albumin (Shibayagi). The cytochrome P450IA1 activity was analyzed by adding ethoxyresorufin (ER) into the culture media at a final concentration of $10 \mathrm{mM}$, incubating for $60 \mathrm{~min}$ and measuring the resorufin production level (Sakai et al., 2002).

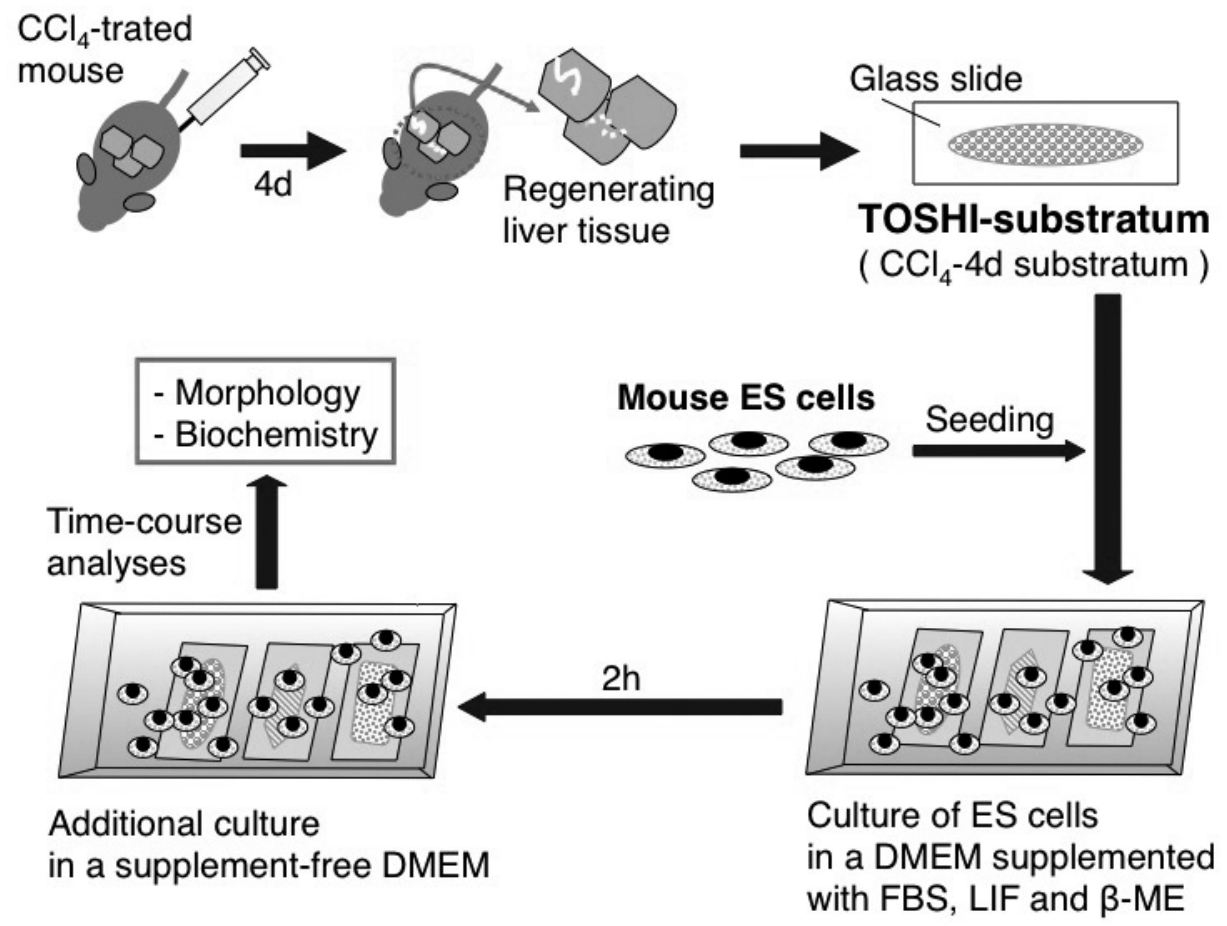

Fig. 5. Experimental protocol of investigating the hepatic differentiation of ES cells cultured on TOSHI-substratum derived from regenerating livers at 4 days after $\mathrm{CCl}_{4}$ administration. 
Consequently, binucleated cells in a polygonal shape appeared in the colonies cultured for $24 \mathrm{~h}$. Albumin secretion into a culture medium and the cytochrome P450IA1 activity metabolizing ER to the dealkylated resorufin were confirmed at 48 and $62 \mathrm{~h}$ in culture, respectively (Fig. 6). Also, the $\mathrm{CCl}_{4}-4 \mathrm{~d}$ substratum alone released albumin and reached to the plateau level of $0.1 \mathrm{ng} / \mathrm{ml}$ until $24 \mathrm{~h}$, however it did not possess the cytochrome P450IA1 activity.

Morphological features

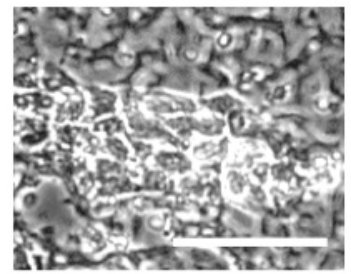

$\mathrm{Bar}=50 \mu \mathrm{m}$

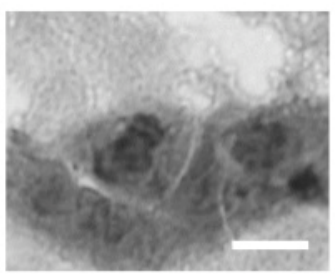

$\mathrm{Bar}=10 \mu \mathrm{m}$

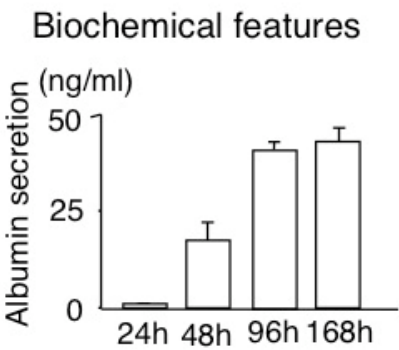

\begin{tabular}{cc}
$\begin{array}{c}\text { Time in } \\
\text { culture }\end{array}$ & $\begin{array}{c}\text { CYP1A1 } \\
\text { activity }\end{array}$ \\
\hline
\end{tabular}

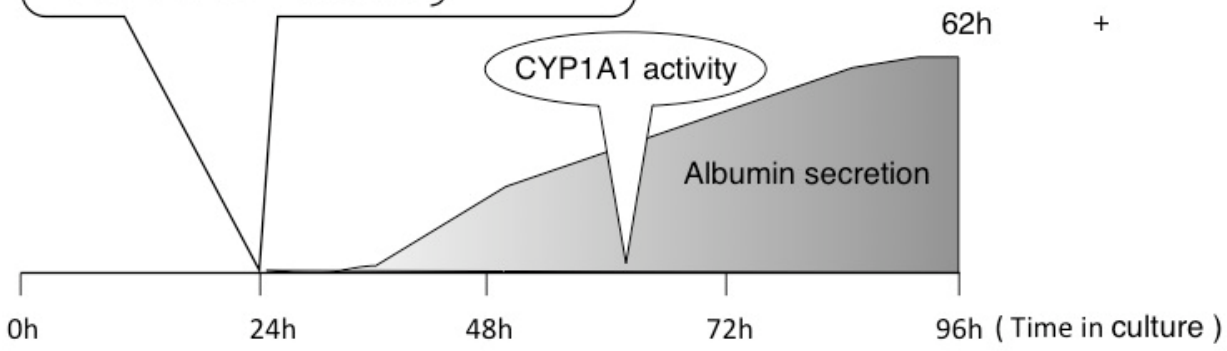

Fig. 6. Hepatic differentiation of ES cells cultured on TOSHI-substratum derived from regenerating livers at 4 days after $\mathrm{CCl}_{4}$ administration.

In this study, we demonstrated that the $\mathrm{CCl}_{4}-4 \mathrm{~d}$ substratum had a high potential to efficiently differentiate ES cells into hepatocyte-like clonies with some functional and morphological characteristics of mature parenchymal hepatocytes within a few days. Thus, we succeeded in directly differentiating ES cells into hepatic cells without the use of any soluble growth factor and also the process of embryoid body formation although either was essential for conventional methods (Ishi et al., 2005; Lavon \& Benvenisty, 2005; Novik et al., 2006; Teratani et al., 2005; Zhou et al., 2007). Also, each TOSHI-substratum prepared from livers in various stages after $\mathrm{CCl}_{4}$-administration into mice had different activities for inducing behavior of ES cells. It is quite interesting that the $\mathrm{CCl}_{4}-15 \mathrm{~d}$ substratum was different from the cont.-substratum and retained the induction activity of differentiation although the mice on 15 days after $\mathrm{CCl}_{4}$-administration showed the normal level of both serum AST and liver PCNA-positive cell index, suggesting that liver regeneration-related factor(s) was deposited in the $\mathrm{CCl}_{4}-15 \mathrm{~d}$ substratum. Such ES cell behavior-regulating 
factor(s) that was sustained on each TOSHI-substratum prepared from $\mathrm{CCl}_{4}$-administrated mouse livers is unclear at present. To investigate the molecular mechanism inducing the different profile of ES cell behavior on each TOSHI-substratum, we are planning to treat the TOSHI-substratum with antibody or enzyme in biological approach, fixation agent or detergent in chemical approach, and/or heat or ultra violet irradiation in physical approach.

\subsection{A new strategy for predicting the toxicity of chemicals}

In the above experiment, the serum AST level indicating liver injury and the number of PCNA-positive cells indicating liver regeneration increased more than twice of the control from $12 \mathrm{~h}$ to $4 \mathrm{~d}$ with the peak (about 3.4-fold of the control) at $24 \mathrm{~h}$ and from $24 \mathrm{~h}$ to $7 \mathrm{~d}$ with the peak (about 27-fold of the control) at $4 \mathrm{~d}$ after $\mathrm{CCl}_{4}$-administration, respectively (Table 1). On the other hand, the initial cell attachability of pALB-EGFP/ES cells to TOSHIsubstrata prepared from livers after $\mathrm{CCl}_{4}$ administration into mice represented $-31 \%$ on the $\mathrm{CCl}_{4}-12 \mathrm{~h}$ and $-11 \%$ on $\mathrm{CCl}_{4}-24 \mathrm{~h}$ substrata whereas $+20 \%$ on the $\mathrm{CCl}_{4}-4 \mathrm{~d}$ and $\mathrm{CCl}_{4}-7 \mathrm{~d}$ substrata in comparison to the control TOSHI-substratum (Table 1). Also, the $\mathrm{CCl}_{4}-48 \mathrm{~h}$, $\mathrm{CCl}_{4}-4 \mathrm{~d}, \mathrm{CCl}_{4}-7 \mathrm{~d}$ and $\mathrm{CCl}_{4}-15 \mathrm{~d}$ substrata showed the induction activity to differentiate the pALB-EGFP/ES cells to the cells expressing GFP (Table 2). These findings suggest that timedependent toxic changes of $\mathrm{CCl}_{4}$ in liver in vivo can be estimated by the cell behaviors of pALB-EGFP/ES cells cultured on the TOSHI-substrata prepared from livers after $\mathrm{CCl}_{4}$ administration into mice.

I think that an organ-specific toxicity level after drug administration or chemical exposure can be defined as not only injury intensity of differentiated cells composing the organ but also regeneration activity of stem cells in the organ. Here, the above study demonstrated that the injury intensity and regeneration activity was predicted by the initial cell attachability and differentiation efficiency of ES cells cultured on the TOSHI-substrata derived from livers after administrating chemical into mice, respectively. Therefore, I propose as a new strategy for predicting the toxicity of drugs or chemicals in human by utilizing the time-course cell behavior of human stem cells cultured on the TOSHI-substrata derived from various organs after exposing some chemical into experimental animals. The human stem cells include ES cells, iPS (induced pluripotent stem) cells and somatic stem cells (e.g. mesenchymal stem cells), (Fig. 7).

\section{A novel concept for drug discovery and development utilizing the behavior of ES cells cultured on TOSHI-substrata}

In this section I describe the recent progress of ES cell-based assay systems for drug discovery and development, then introduce advantages of the ES cell-based assay system utilizing TOSHI-substrata in drug discovery and development.

\subsection{Recent progress of ES cell-based assay systems for drug discovery and development}

ES cells are pluripotent stem cells possessing the capacity for self-renewal of proliferating indefinitely and multilineage differentiation. Therefore, ES cells generally function as a ready source of large quantities of partially differentiated progenitors or terminally differentiated specialized cells, which serve as cell-based assay systems (Sartipy et al., 2007). Somatic stem cell marker prominin-1/CD133, a plasma membrane marker is expressed in 

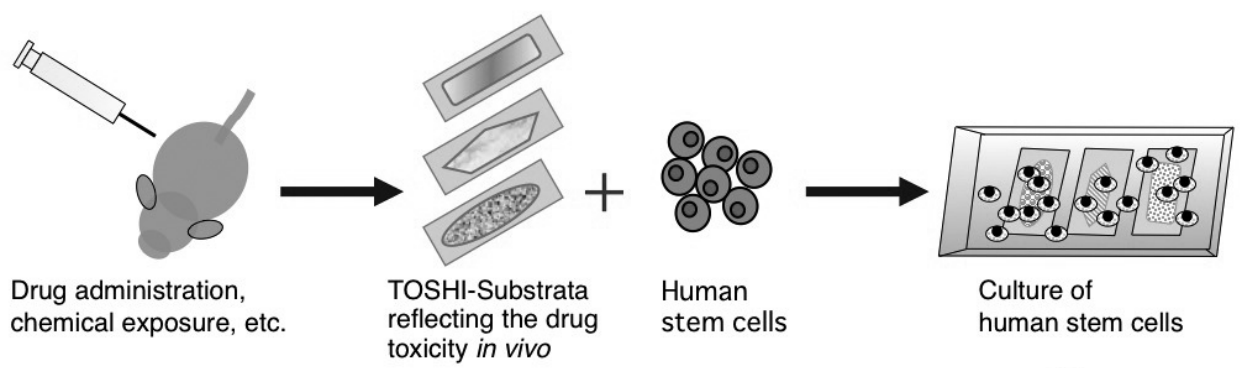

Human stem cells

Culture of human stem cells

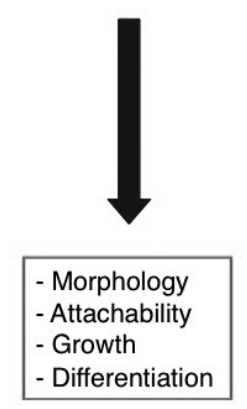

Time-course analyses of human cell behavior

Fig. 7. A novel strategy for extrapolating the toxicity in vivo utilizing TOSHI-substrata.

ES-derived progenitors but not in differentiated cells (Kania et al., 2005). ES-derived somatic stem cells such as hematopoietic and neural stem cells and also ES-derived differentiated mature cells such as cardiomyocytes and hepatocytes have been utilized for drug screening and toxicity assessment as ES cell-based assay systems in vitro (Kettenhofen \& Bohlen, 2008; Kuegler et al., 2010; Ma et al., 2008; Sartipy et al., 2007). Recently, various high-throughput cellular microarray platforms have been developed in a viewpoint for applying ES cells to drug discovery and development (Derda et al., 2007; Flaim et al., 2008). Consequently, it has been realized that the ability to track stem cell fate decisions and to quantify specific stem cell markers on microarray platforms has the potential to increase our understanding of the cellular mechanisms involved. Here, signals emanating from the stem cell microenvironment, or niche, are crucial in regulating stem cell fate. These signals include physical cues (e.g. matrix elasticity, cell-cell and cell-ECM interactions) and soluble factors (e.g. growth factors and small molecules) (Fernandes et al., 2009).

\subsection{Advantages of the ES cell-based assay system utilizing TOSHI-substrata in drug discovery and development}

The greatest merit of utilizing TOSHI-substrata is to provide niches reflecting various conditions in tissue(s)/organ(s) in vivo towards ES cells, resulting in the generation of assay systems for estimating not only biological activity but also the drug efficacy and chemical toxicity remained in the TOSHI-substrata by analyzing the behavior of the ES cells. Therefore, it is available to propose new research strategies for exploring bioactive molecule(s) involved in the TOSHI-substrata and/or for extrapolating pharmacological and 
toxicological effect(s) of chemicals in human. As the exploration research, bioactive molecules such as ligand, growth factor, growth inhibitor and differentiation-inducing factor would be isolated from specific regions in the TOSHI-substrata where ES cells revealed behaviors such as adhesion, proliferation, apoptosis and differentiation, respectively. Also, as the pharmacological and toxicological research, the TOSHI-substrata would provide two applications. One is means for efficiently differentiating human ES cells to sufficient amount of mature differentiated cells (e.g. hepatocytes) by utilizing the TOSHIsubstrata derived from a regenerating tissue/organ. The other is a novel extrapolation system of the drug efficacy and/or toxicity by investigating the behavior of human ES cells cultured on the TOSHI-substrata derived from every tissue/organ of experimental animals after administrating drugs and/or exposing chemicals, respectively (Fig. 7).

\section{Conclusions}

I presented the basics and advantages of a cell culture system utilizing TOSHI (tissue/organ sections for histopathology)-substrata, and introduced a new platform for orienting differentiation of mouse ES cells towards hepatic lineage utilizing TOSHI-substrata derived from regenerating liver after $\mathrm{CCl}_{4}$-administration into mice. Also, I proposed a new strategy for applying the ES cell-based assay system utilizing TOSHI-substrata to the researches in drug discovery and development. I hope that such a new strategy could contribute not only to expand the utility of ES cells but also to generate a high-throughput assay system utilizing TOSHI-substrata as a tissue/organ microarray useful for extrapolating drug efficacy and chemical toxicity in human body.

\section{Acknowledgments}

This work is being partly supported by grants for the Pioneer Research from the Ministry of Agriculture, Forestry and Fisheries of Japan and for general research from the National Institute of Agrobiological Sciences. I would like to thank Dr. T. Ochiya, Dr. T. Takeuchi, Dr. K. Yanagihara, Dr. S. Terada, Dr. M. Watanabe, Mr. N. Suzuki, Mr. Y. Hamanaka and Ms. Y. Ohsumi.

\section{References}

Derda, R.; Li, L.; Orner, B. P.; Lewis, R. L.; Thomson, J. A. \& Kiessling, L. L. (2007). Defined substrates for human embryonic stem cell growth identified from surface arrays. ACS Chemical Biology, Vol.2, No.5, 347-355.

Fernandes, T. G.; Diogo, M. M.; Clark, D. S.; Dordick, J. S. \& Cabral, J. M. (2009). Highthroughput cellular microarray platforms: applications in drug discovery, toxicology and stem cell research. Trends in Biotechnology, Vol.27, No.6, 324-329.

Flaim, C. J.; Teng, D.; Chien, S. \& Bhatia, S. N. (2008). Combinatorial signaling microenvironments for studying stem cell fate. Stem Cells and Development, Vol.17, No.1, 29-39.

Harada, K.; Mitaka, T.; Miyamoto, S.; Sugimoto, S.; Ikeda, S.; Takeda, H.; Mochizuki, Y. \& Hirata, K. (2003). Rapid formation of hepatic organoid in collagen sponge by rat small hepatocytes and hepatic nonparenchymal cells. Journal of Hepatology, Vol.39, No.5, 716-723. 
Ishi, T.; Yasuchika, K.; Fujii, H.; Hoppo, T.; Baba, S.; Naito, M.; Machimoto, T.; Kamo, N.; Suemori, H.; Nakatsuji, N. \& Ikai, I. (2005). In vitro differentiation and maturation of mouse embryonic stem cells into hepatocytes. Experimental Cell Research, Vol.309, No.1, 68-77.

Kania, G.; Corbeil, D.; Fuchs, J.; Tarasov, K. V.; Blyszczuk, P.; Huttner, W. B.; Boheler, K. R. \& Wobus, A. M. (2005). Somatic stem cell marker prominin-1/CD133 is expressed in embryonic stem cell-derived progenitors. Stem Cells, Vol.23, No.6, 791-804.

Kettenhofen, R. \& Bohlen, H. (2008). Preclinical assessment of cardiac toxicity. Drug Discovery Today, Vol.13, No.15-16, 702-707.

Kuegler, P. B.; Zimmer, B.; Waldmann, T.; Baudis, B.; Ilmjärv, S.; Hescheler, J.; Gaughwin, P.; Brundin, P.; Mundy, W.; Bal-Price, A. K.; Schrattenholz, A.; Krause, K. H.; van Thriel, C.; Rao, M. S.; Kadereit, S. \& Leist, M. (2010). Markers of murine embryonic and neural stem cells, neurons and astrocytes: reference points for developmental neurotoxicity testing. ALTEX, Vol.27, No.1, 17-42.

Lavon, N. \& Benvenisty, N. (2005). Study of hepatocyte differentiation using embryonic stem cells. Journal of Cellular Biochemistry, Vol.96, No.6, 1193-1202.

Ma, F.; Ebihara, Y.; Umeda, K.; Sakai, H.; Hanada, S.; Zhang, H.; Zaike, Y.; Tsuchida, E.; Nakahata, T.; Nakauchi, H. \& Tsuji, K. (2008). Generation of functional erythrocytes from human embryonic stem cell-derived definitive hematopoiesis. Proceedings of the National Academy of Sciences of the United States of America, Vol.105, No.35, 1308713092.

Novik, E. I.; Maguire, T. J.; Orlova, K.; Schloss, R. S. \& Yarmush, M. L. (2006). Embryoid body-mediated differentiation of mouse embryonic stem cells along a hepatocyte lineage: Insights from gene expression profiles. Tissue Engineering, Vol.12, No.6, 1515-1525.

Sakai, Y.; Jiang, J.; Kojima, N.; Kinoshita, T. \& Miyajima, A. (2002). Enhanced in vitro maturation of fetal mouse liver cells with oncostatin $\mathrm{M}$, nicotinamide, and dimethyl sulfoxide. Cell Transplantation, Vol.11, No.5, 435-441.

Sartipy, P.; Björquist, P.; Strehl, R. \& Hyllner, J. (2007). The application of human embryonic stem cell technologies to drug discovery. Drug Discovery Today, Vol.12, No.17-18, 688-699.

Takeuchi, T.; Ochiya, T. \& Takezawa, T. (2008). Tissue array substratum composed of histological sections: a new platform for orienting differentiation of embryonic stem cells towards hepatic lineage. Tissue Engineering Part A, Vol.14, No.2, 267-274.

Takezawa, T.; Mori, Y. \& Yoshizato, K. (1990). Cell culture on a thermo-responsive polymer surface. Bio/Techonology (N.Y.) (currently, Nature Biotechnology), Vol.8, No.9, 854-856.

Takezawa, T.; Yamazaki, M.; Mori, Y.; Yonaha, T. \& Yoshizato, K. (1992). Morphological and immuno-cytochemical characterization of a hetero-spheroid composed of fibroblasts and hepatocytes. Journal of Cell Science, Vol.101, No.3, 495-501.

Takezawa, T. \& Yoshizato, K. (1997). Mass transport via naturally branched scaffolds maintains viability of a reconstituted model of connective tissue. Tissue Engineering, Vol.3, No.4, 329-343.

Takezawa, T.; Inoue, M.; Aoki, S.; Sekiguchi, M.; Wada, K.; Anazawa, H. \& Hanai, N. (2000). Concept for organ engineering: A reconstruction method of rat liver for in vitro culture. Tissue Engineering, Vol.6, No.6, 641-500. 
Takezawa, T.; Takenouchi, T.; Imai, K.; Takahashi, T. \& Hashizume, K. (2002). Cell culture on thin tissue sections commonly prepared for histopathology. The FASEB Journal, Vol.16, No.13, 1847-1849. (http:/ / www.fasebj.org/cgi/doi/10.1096/fj.02-0405fje)

Takezawa, T. (2003). A strategy for the development of tissue engineering scaffolds that regulate cell behavior. Biomaterials, Vol.24, No.13, 2267-2275.

Takezawa, T.; Ozaki, K.; Nitani, A.; Takabayashi, C. \& Shimo-Oka, T. (2004). Collagen vitrigel: A novel scaffold that can facilitate a three-dimensional culture for reconstructing organoids. Cell Transplantation, Vol.13, No.4, 463-473.

Takezawa, T.; Ozaki, K. \& Takabayashi, C. (2007a). Reconstruction of a hard connective tissue utilizing a pressed silk sheet and type-I collagen as the scaffold for fibroblasts. Tissue Engineering, Vol.13, No.6, 1357-1366.

Takezawa, T.; Takeuchi, T.; Nitani, A.; Takayama, Y.; Kino-oka, M.; Taya, M. \& Enosawa, S. (2007b). Collagen vitrigel membrane useful for paracrine assays in vitro and drug delivery systems in vivo. Journal of Biotechnology, Vol.131, No.1, 76-83.

Takezawa, T.; Takeuchi, T.; Yanagihara, K.; Nakazawa, Y.; Nitani, A.; Terada, S.; Ochiya, T. \& Ueno, K. (2008a). Advantages of culture models utilizing substrata made of TOSHI (tissue/organ sections for histopathology) or collagen vitrigel membrane and their application concept for drug development researches. Yakugaku Zasshi, Vol.128, No.1, 51-60 [in Japanese].

Takezawa, T.; Takeuchi, T.; Ochiya, T.; Yanagihara, K.; Terada, S.; Suzuki, N. \& Watanabe, M. (2008b). Advanced research utilizing histopathological sections as a culture substratum of animal cells. Organ Biology, Vol.15, No.2, 107-114 [in Japanese].

Takezawa, T.; Fukuda, M.; McIntosh-Ambrose, W.; Ko, J-A.; Elisseeff, J.; Haga, S.; Ozaki, M.; Kato, K.; Wang, P.C.; Uchino, T. \& Nishida, T. (2010). Development of novel cell culture systems utilizing the advantages of collagen vitrigel membrane. Yakugaku Zasshi, Vol.130, No.4, 565-574 [in Japanese].

Teratani, T.; Yamamoto, H.: Aoyagi, K.; Sasaki, H.; Asari, A.; Quinn, G.; Sasaki, H.; Terada, M. \& Ochiya, T. (2005). Direct hepatic fate specification from mouse embryonic stem cells. Hepatology, Vol.41, No.4, 836-846.

Yamamoto, H.; Quinn, G.; Asari, A.; Yamanokuchi, H.; Teratani, T.; Terada, M. \& Ochiya T. (2003). Differentiation of embryonic stem cells into hepatocytes: biological functions and therapeutic application. Hepatology, Vol.37, No.5, 983-993.

Yanagihara, K.; Takeuchi, T.; Terada, S.; Miki, M. \& Takezawa, T. (2007) Cell behaviors of two different cell lines on the section substrata prepared from rat organs and their mathematical models. Alternatives to Animal Testing and EXperimentation, Vol.12, Supplement, 126.

Zhou, Q. J.; Xiang, L. X.; Shao, J. Z.; Hu, R. Z.; Lu, Y. L.; Yao, H. \& Dai, L. C. (2007). In vitro differentiation of hepatic progenitor cells from mouse embryonic stem cells induced by sodium butyrate. Journal of Cellular Biochemistry, Vol.100, No.1, 29-42. 


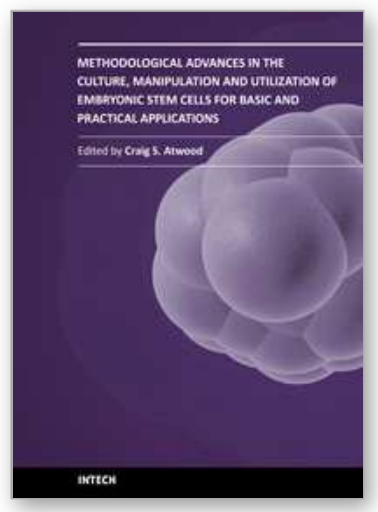

\author{
Methodological Advances in the Culture, Manipulation and \\ Utilization of Embryonic Stem Cells for Basic and Practical \\ Applications \\ Edited by Prof. Craig Atwood
}

ISBN 978-953-307-197-8

Hard cover, 506 pages

Publisher InTech

Published online 26, January, 2011

Published in print edition January, 2011

Pluripotent stem cells have the potential to revolutionise medicine, providing treatment options for a wide range of diseases and conditions that currently lack therapies or cures. This book describes methodological advances in the culture and manipulation of embryonic stem cells that will serve to bring this promise to practice.

\title{
How to reference
}

In order to correctly reference this scholarly work, feel free to copy and paste the following:

Toshiaki Takezawa (2011). A Novel Strategy for Drug Discovery and Development by Analyzing the Behavior of ES Cells Cultured on TOSHI (Tissue/Organ Sections for Histopathology)-Substrata, Methodological Advances in the Culture, Manipulation and Utilization of Embryonic Stem Cells for Basic and Practical Applications, Prof. Craig Atwood (Ed.), ISBN: 978-953-307-197-8, InTech, Available from:

http://www.intechopen.com/books/methodological-advances-in-the-culture-manipulation-and-utilization-ofembryonic-stem-cells-for-basic-and-practical-applications/a-novel-strategy-for-drug-discovery-anddevelopment-by-analyzing-the-behavior-of-es-cells-cultured-o

\section{INTECH}

open science | open minds

\section{InTech Europe}

University Campus STeP Ri

Slavka Krautzeka 83/A

51000 Rijeka, Croatia

Phone: +385 (51) 770447

Fax: +385 (51) 686166

www.intechopen.com

\section{InTech China}

Unit 405, Office Block, Hotel Equatorial Shanghai

No.65, Yan An Road (West), Shanghai, 200040, China

中国上海市延安西路65号上海国际贵都大饭店办公楼405单元

Phone: +86-21-62489820

Fax: $+86-21-62489821$ 
(C) 2011 The Author(s). Licensee IntechOpen. This chapter is distributed under the terms of the Creative Commons Attribution-NonCommercialShareAlike-3.0 License, which permits use, distribution and reproduction for non-commercial purposes, provided the original is properly cited and derivative works building on this content are distributed under the same license. 